\title{
Review
}

\section{Insulin action and insulin resistance in human skeletal muscle}

\author{
J.R. Zierath ${ }^{1}$, A. Krook ${ }^{2}$, H. Wallberg-Henriksson ${ }^{2}$ \\ ${ }^{1}$ Department of Clinical Physiology, Karolinska Hospital, Stockholm, Sweden \\ ${ }^{2}$ Department of Physiology and Pharmacology, Karolinska Institute, Stockholm Sweden
}

Keywords Exercise, glucose transport, hyperglycaemia, insulin signalling, obesity.

\section{Introduction}

The pivotal role in vivo of insulin is to control fuel homeostasis. Insulin exerts its effect on three main target tissues: liver, fat and skeletal muscle. Resistance to the normal action of insulin contributes to the pathogenesis of a number of common human disorders, including Type I (insulin-dependent) and Type II (non-insulin-dependent) diabetes mellitus, hypertension and the metabolic syndrome $\mathrm{x}$, thus constituting a major public health problem. Environmental factors such as poor nutrition (high-fat diet) or inactivity (lower oxygen consumption i.e. $\mathrm{VO}_{2 \max }$ ) or both also seem to have a major effect on the development of peripheral insulin resistance [1-4]. Although the primary defect in the pathogenesis of Type II diabetes is not known, a combination of genetic and environmental factors probably contribute to the manifestation of this progressive metabolic disorder, which is usually not apparent clinically until mid-life. Type II diabetic patients are characterised by fasting hyperglycaemia and by increased, normal or low concentrations of insulin. Any one of these could be a cause or consequence of defects in insulin secretion from the beta cell or peripheral insulin resistance in skeletal muscle or adipose tissue. Defects in insulin

Corresponding author: J. R. Zierath, Associate Professor, Department of Clinical Physiology, Karolinska Hospital, S-171 76 Stockholm, Sweden

Abbreviations: IR, Insulin receptor; IRS, insulin receptor substrate; PI, phosphatidylinositol; PKC, protein kinase C; DAG, diacylglyceride; ATB-BMPA, 2-N-4-(1-azi-2,2,2-trifluoroethyl)benzoyl-1,3-bis(d-mannose-4-yloxy)-2-propylamine; GK, Goto-Kakizaki; MAP, mitogen-activated protein; HK, hexokinase. secretion have been noted in lean or normal weight patients with Type II diabetes [5, 6] and insulin resistance in skeletal muscle has been reported in Type II diabetic patients regardless of weight [7]. Skeletal muscle is the principal tissue responsible for insulinstimulated glucose disposal [8] and the major site of peripheral insulin resistance [9]. Intense interest has been focused on explaining the molecular basis for the development of insulin resistance in skeletal muscle in an effort to control and improve whole-body glucose homeostasis. This review is focused on current understanding of the molecular mechanisms regulating insulin action and the factors contributing to insulin resistance in human skeletal muscle.

\section{Whole-body insulin resistance in Type II diabetic patients}

Most of our current understanding of the mechanisms involved in development of insulin resistance has evolved from in vivo studies of insulin action in diabetic animals and humans using the euglycaemic hyperinsulinaemic clamp technique, with or without radioactive tracers, developed nearly 20 years ago by DeFronzo and colleagues $[9,10]$. In vivo studies show that skeletal muscle is the principal site of glucose uptake under insulin-stimulated conditions, accounting for approximately $75 \%$ of glucose disposal after glucose infusion $[8,9,11]$. In the postprandial state, insulin-mediated glucose uptake and utilisation is greatly impaired in Type II diabetic patients $[9,12$, $13]$ and in glucose tolerant first-degree relatives [12, 14]. From in vivo tracer studies, the defect in wholebody glucose uptake in Type II diabetic patients has been localised to the non-oxidative pathway for glucose metabolism $[8,13,15,16]$. Thus, in vivo methods have provided valuable, yet indirect evidence, to suggest that the reduced rate of non-oxidative glucose 
metabolism observed in Type II diabetic patients results from a defect at the level of glucose transport, glucose phosphorylation or glycogen synthase. In the past decade, several key proteins have been identified which are believed to be important for insulin signal transduction to metabolic and mitogenic responses. Consequently, it is now possible to study cellular, as well as whole-body systems, to explain the molecular basis for the development of peripheral insulin resistance.

\section{Regulation of glucose transport: insulin signal transduction}

Initial events related to tyrosine phosphorylation. After insulin binds to the insulin receptor (Fig. 1), the tyrosine kinase activity of the insulin receptor (IR) $\beta$ subunit is activated and several key proteins within the cell are phosphorylated, including the insulin receptor substrates (IRS) and Shc [17-19]. To date, four different IRS molecules have been cloned [19]. Evidence is emerging that the different IRS molecules have specialised roles in mediating metabolic and mitogenic effects of insulin [20, 21]. In skeletal muscle, IRS-1 and IRS-2 appear to be the predominant isoforms expressed. Insulin receptor substrate proteins act as docking proteins for downstream signalling molecules containing Src homology 2 domains, including the $85000 \mathrm{M}_{\mathrm{r}}$ regulatory subunit of phosphatidylinositol (PI) 3-kinase [22]. Phosphatidylinositol 3-kinase has been implicated as a key signalling transducer in insulin-mediated glucose transport in skeletal muscle and adipocytes [23-25]. In 3T3-L1 adipocytes, IRS-1/2 and PI 3-kinase are targeted to intracellular locations, such as the actin cytoskeleton [26, 27]. Thus, signals for glucose transport seem to be compartmentalised within the cell. Recent studies provide evidence for several PI 3-kinase adapter subunit variants in skeletal muscle that have

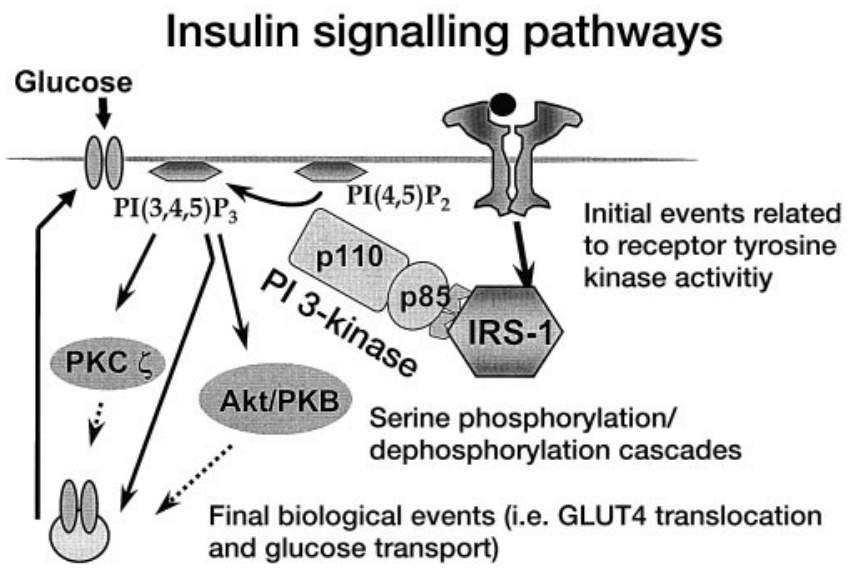

Fig. 1. Simplified outline of insulin signalling in skeletal muscle. PKB, protein kinase B different insulin-induced PI 3-kinase responses [28-31]. Insulin can recruit multiple adapter subunit isoforms of PI-3 kinase in human skeletal muscle [31]. Four different adapter subunit isoforms contribute to insulin-dependent PI-3 kinase signalling pathways in human skeletal muscle. Similar observations have been made in rodent skeletal muscle [28-30]. The different isoforms of the regulatory subunits have different insulin-induced responses that increase PI 3-kinase and this could provide mechanisms by which specificity is achieved in insulin signalling. The molecular link between PI 3-kinase and glucose transport is not known. Thus, enormous efforts are now being placed on identifying the molecules downstream of PI 3-kinase that are linked to glucose transport.

Serine phosphorylation downstream of PI 3-kinase. The serine/threonine kinase Akt is a downstream target of PI 3-kinase [32-34] and has been implicated as a component of the insulin-signalling pathway to glucose transport [35-39]. Whether Akt is directly coupled to glucose transport is still a topic of debate. Overexpression of an Akt mutant in which the two phosphorylation sites targeted by growth factors are mutated leads to inhibition of both insulin-induced activation of Akt and insulin-stimulated protein synthesis [40] but has no effect on insulin-stimulated glucose uptake in 3T3-L1 adipocytes [40] and L6 muscle myoblasts [39]. When the catalytic site of Akt was, however, also mutated, generating a triple Akt mutant, insulin-mediated GLUT4 translocation was inhibited [39]. These data provide strong evidence that both the phosphorylation sites and the catylic sites are important for sending the insulin signal downstream from Akt to glucose transport.

Other downstream candidates in the insulin-signalling pathway to glucose transport included members of the protein kinase C (PKC) family. The PKC family consists of at least 12 serine/threonine kinase isoforms that phosphorylate and activate multiple proteins. The conventional PKC isoforms include $\alpha$, $\beta$, and $\gamma$ and are activated by $\mathrm{Ca}^{2+}$, phosphatidylserine and diacylglyceride (DAG); the novel isoforms include $\delta, \varepsilon, \eta$ and $\vartheta$ and are $\mathrm{Ca}^{2+}$-independent and activated by phosphatidylserine and DAG; and the atypical PKC isoforms include $\zeta$ and $\lambda$ and are insensitive to $\mathrm{Ca}^{2+}$ and DAG [41]. In several different cell culture systems, PKCs have been shown to be important regulators of cell growth, differentiation and metabolism [42, 43]. Isoforms of PKC differ substantially in terms of structure, regulation, tissue distribution, expression throughout development, and substrate specificity. The basic mechanism of action for most PKC isoforms involves translocation from cytosol to cellular membranes and a subsequent response to changes in intracellular $\mathrm{Ca}^{2+}$ or 1,2-DAG concentration $[42,43]$. The exact mechanism regulating iso- 
form-specific PKC activation in skeletal muscle is poorly defined. It is believed that PKCs stimulate glucose transport in skeletal muscle by a mechanism distinct from the insulin and hypoxia pathways [44]. In cell culture systems, two atypical protein kinase $\mathrm{C}$ isoforms, $\mathrm{PKC} \lambda$ and $\mathrm{PKC}-\zeta$, have been reported to be activated by insulin through a PI 3-kinase-dependent mechanism [45, 46], and have been implicated as having a role in insulin-stimulated glucose transport. Adenovirus-mediated overexpression of a dominant-negative kinase dead mutant of PKC $\lambda$ inhibited insulin-stimulated glucose transport by $60 \%$ in 3T3L1 adipocytes [47]. Similarly, stable overexpression of wild-type $\mathrm{PKC}-\zeta$ increased and a dominant-negative mutant form of PKC- $\zeta$ decreased basal and insulin-stimulated glucose transport in 3T3-L1 fibroblasts and adipocytes [48]. Thus, atypical PKC isoforms seem to mediate insulin signal transduction downstream of PI 3-kinase. Nevertheless, the physiological role of PKC $\zeta$ or $\lambda$ has not yet been shown in human skeletal muscle. Data on the expression and regulation of the different PKC isoforms in human skeletal muscle is lacking.

Final biological event of glucose transport. Multiple lines of evidence suggest that PI 3-kinase has a central role in mediating insulin signalling to glucose transport in skeletal muscle [23-25]. Insulin stimulates glucose uptake in skeletal muscle primarily by eliciting translocation of GLUT4 from an intracellular pool to the plasma membrane [49-51]. Glucose transporter 4 is the predominant glucose transporter isoform expressed in skeletal muscle [52-54] and it catalyses this rate-limiting step for glucose uptake and metabolism [55-57]. Its translocation is a complex process involving membrane vesicle trafficking and sorting machinery (Fig. 2). The steps in the GLUT4translocation process include budding or release of GLUT4 from an intracellular reservoir compartment,

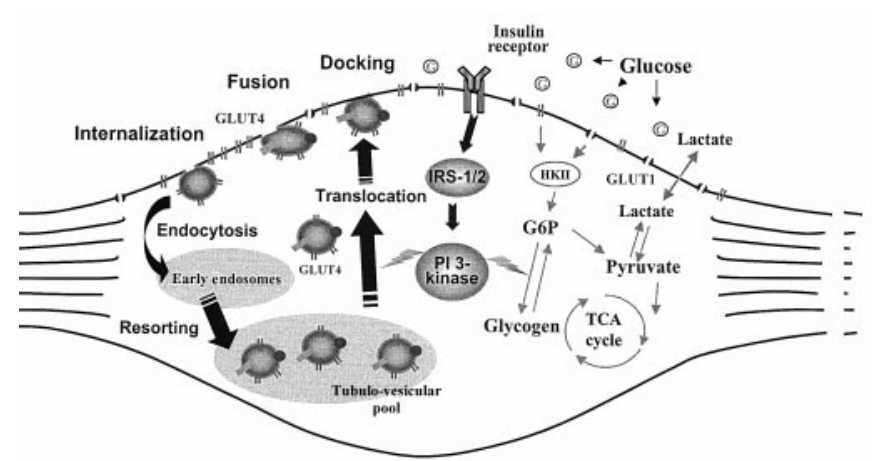

Fig. 2. Working hypothesis of cellular GLUT4 traffic. GLUT4 translocates from an intracellular storage site to the plasma membrane. The GLUT4 vesicle is believed to dock, fuse with the plasma membrane and undergo a transition from an occluded to a fully functionally active state to facilitate the glucose transport into the cell. TCA, trichloroacetic acid transit to the plasma membrane and docking and fusion with the plasma membrane [58]. Thus, there are many potential steps at which GLUT4 translocation could be impaired in diabetic skeletal muscle. In human skeletal muscle, insulin elicits a translocation of GLUT4 from internal membranes to the plasma membrane [51], a finding consistent with studies using rat skeletal muscle [49-51]. Because the majority of the studies to assess signal transduction and glucose transport have been done in cell culture systems or in diabetic animals, little is known of the regulation of these processes under physiological conditions in Type II diabetic patients.

\section{Insulin resistance in skeletal muscle from Type II diabetic patients}

Techniques to study human skeletal muscle in vitro. Since the initial observation that skeletal muscle is quantitatively an important site of insulin resistance in Type II diabetic patients [9], the molecular basis of peripheral insulin resistance has been a major challenge to analyse in the intact human. Clearly, wholebody studies of glucose metabolism in humans are essential to further our understanding of metabolic disorders associated with alterations in glucose homeostasis. In vitro methods are, however, also required to study insulin action directly in the muscle tissue. In 1998 a new surgical biopsy procedure to obtain rectus abdominal skeletal muscle specimens under general anaesthesia was presented [59]. Muscle strips were incubated in vitro in the presence of pharmacological concentrations of insulin and glucose transport was reported to be greatly impaired in morbidly obese $\left(\mathrm{BMI} \sim 50 \mathrm{~kg} / \mathrm{m}^{2}\right)$ people with or without Type II diabetes. With this methodological advance it is now possible to do detailed studies of insulin action on intracellular events in diabetic human skeletal muscle.

Glucose transport in skeletal muscle from Type II diabetic patients. Defects in insulin-stimulated glucose transport are not limited to morbidly obese people [60]. In rectus abdominal skeletal muscle biopsy specimens from lean to moderately overweight Type II diabetic patients, a profound reduction in insulin-stimulated 3-O-methylglucose transport was noted at physiological and pharmacological insulin concentrations (Fig. 3). In these studies, 3- $O$-methylglucose, a glucose analogue that is transported into the cell by the glucose transporters but is not further metabolised, was used to assess glucose transport. The rate of intracellular accumulation of 3-O-methylglucose is an index of the rate of glucose transport and is not influenced by subsequent steps in glucose metabolism [61]. This suggests that insulin resistance in skeletal muscle from Type II diabetic patient is due to defects 


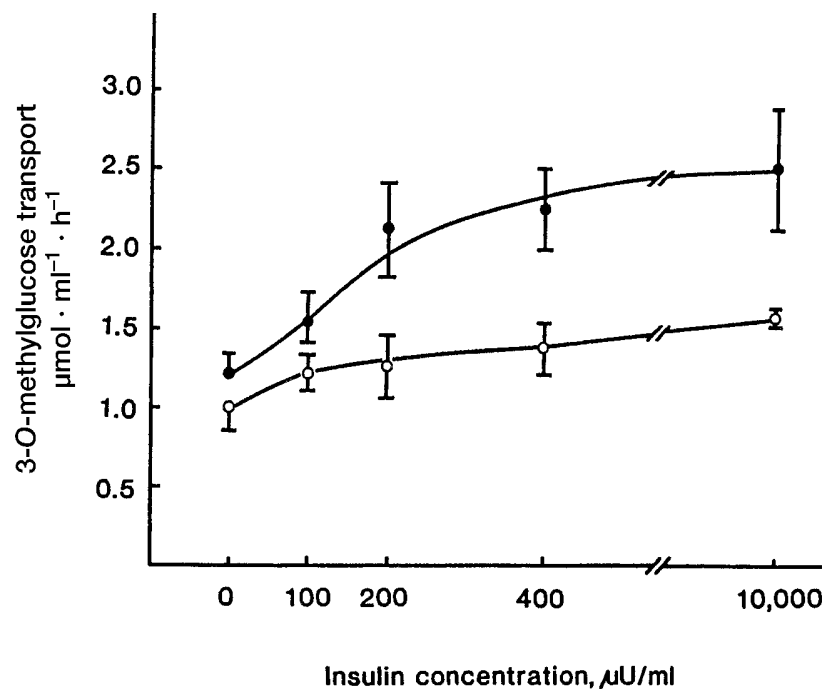

Fig.3. Insulin-stimulated glucose transport in human skeletal muscle. Basal and insulin-stimulated 3-O-methylglucose glucose transport was assessed in isolated rectus abdominus skeletal muscle obtained from age- and weight-matched healthy and Type II diabetic subjects. Reproduced from Andreasson et al. [60] with permission from Acta Physiologica Scandinavica

in glucose transport. Reduced insulin-mediated glucose transport is not limited to Type II diabetic patients because similar defects are noted in muscle from insulin-resistant rodents [62-69].

Comparison between whole-body and cellular studies of glucose uptake. In vitro $[3,59,60,70,71]$ and in vivo $[16,72]$ studies in rodents and humans show that the decrease in insulin-mediated peripheral glucose uptake can be localised to a defect in the mechanism involved in insulin action at the level of glucose transport in skeletal muscle. Strikingly, regardless of technique (in vitro vs in vivo), insulin increased glucose transport twofold to fivefold in skeletal muscle from control subjects, with minimal effects noted in Type II diabetic patients. Furthermore, using both techniques, the rate of insulin-stimulated glucose transport in skeletal muscle is reduced by about $50 \%$ in Type II diabetic patients [16, 60, 71, 73]. Thus, insulin action on glucose transport seems to be the first step in peripheral glucose utilisation that is impaired in Type II diabetic patients. Whether this is a permanent defect or a short-term down-regulation secondary to the diabetic state is, however, still needs to be explained.

Additional methods to study human skeletal muscle. Despite the indisputable novelty of the rectus abdominal muscle preparation, there are caveats associated with this procedure. For example, general anaesthesia is required during the surgery and this could alter insulin action or glucose metabolism in skeletal muscle. In addition, surgical trauma is asso- ciated with altered insulin action and reduced glucose transport in skeletal muscle [74]. With the rectus abdominal muscle preparation, surgical stress is impossible to avoid and the extent to which this alters glucose metabolism in the muscle biopsy specimen is not known. Finally, from a practical point of view, there is an inherent dependency upon choosing subjects from a limited number of patients undergoing abdominal surgery, making it a challenge to carefully match study groups. Thus, we have developed an open biopsy procedure to obtain vastus lateralis skeletal muscle under local anaesthesia. One advantage of the open muscle biopsy technique is that the investigator is not limited to choosing patients undergoing surgery, thus giving greater freedom to select the patient group and control subjects. Furthermore, surgical trauma and general anaesthesia can be avoided. Finally, subjects can be matched for age, physical activity, BMI and various other characteristics known to influence insulin sensitivity.

Studies of GLUT4 traffic in skeletal muscle. Using a sensitive exofacial bis-mannose photolabelling technique (ATB $\left.2-{ }^{3} \mathrm{H}\right] \mathrm{BMPA}$ bis-mannose), stimulation of vastus lateralis muscle from healthy young subjects leads to an increase in the cell surface content of GLUT4 [75]. Maximum insulin stimulation increased cell surface GLUT4 contents and glucose transport twofold. Importantly, insulin-stimulated 3- $O$-methylglucose is strongly correlated with cell surface GLUT4 content. Furthermore, the calculated turnover rate of GLUT4 is not affected by insulin. Thus, the major mechanism for insulin-stimulated glucose transport in human skeletal muscle is GLUT4 translocation to the plasma membrane. With the use of new bis-mannose photolabels [76] it is now possible to quantify the magnitude of the insulin response on GLUT4 translocation in skeletal muscle from Type II diabetic patients. Furthermore, using this technique, dose-response relations for insulin-stimulated glucose transport and cell surface GLUT4 content can be assessed in skeletal muscle from the same subject. Studies of the regulation of GLUT4 traffic are essential to our understanding the underlying mechanism for the development of insulin resistance, which is associated with many disease states including diabetes and obesity. Overcoming defects in the insulin signal transduction pathway leading to GLUT4 translocation is likely to improve glucose homeostasis in the diabetic patient.

\section{Defects in insulin signal transduction skeletal muscle}

Early steps in the insulin-signalling cascade. Intense interest has now focused on whether the reduced insulin-mediated glucose transport in muscle from 
Table 1. Regulation of insulin signalling in skeletal muscle from insulin resistant and Type II diabetic subjects

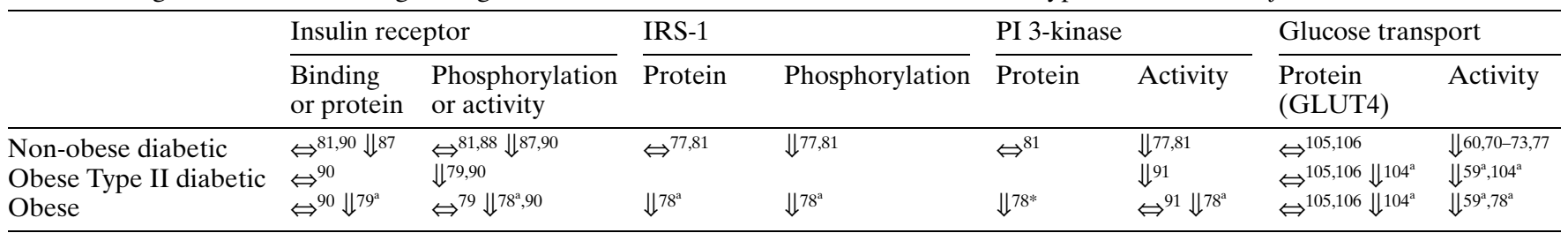

${ }^{a}$ Decreases in muscle from morbidly obese subjects

people with Type II diabetes results from alterations in the insulin signal transduction pathway $[19,71$, 77-81] or from alterations in either traffic or translocation of GLUT4 to the plasma membrane $[82,83]$. Evidence from animal studies suggests that insulinsignalling defects in muscle are associated with altered whole-body glucose homeostasis [64, 69, 84-86]. Early and intermediate steps in the insulin signalling cascade including the IR, IRS-1, and PI 3-kinase are candidates for defects leading to reduced glucose transport in skeletal muscle from obese insulin-resistant subjects and Type II diabetic patients (Table 1). In morbidly obese humans [78] and obese rodents $[64,69,84-86]$, impaired insulinstimulated glucose transport in skeletal muscle is associated with decreased IR and IRS- 1 protein content, decreased IR and IRS-1 phosphorylation and reduced PI 3-kinase activity. Recently, evidence has been provided for altered protein expression of the regulatory subunit of PI 3-kinase in muscle and liver of Zucker Fatty rats [30]. In contrast to the obese state, in hyperglycaemic, hypoinsulinaemic states, such as in the streptozotocin-induced diabetic rat, IR and IRS-1 phosphorylation and PI 3-kinase activity are enhanced in skeletal muscle $[84,86]$, despite reduced insulin-stimulated glucose transport [66]. The extent to which these signalling defects are, however, causative in the development of insulin resistance or secondary to the altered metabolic state associated with Type II diabetes, is currently not known.

In skeletal muscle from non-obese Type II diabetic subjects, IR phosphorylation is reduced [87] or unchanged $[81,88]$ compared with non-diabetic subjects. In lean to moderately obese Type II diabetic subjects, reduced IRS-1 tyrosine phosphorylation and PI 3-kinase activity has been observed in skeletal muscle [77]. Specifically, a rise in serum insulin concentrations from approximately 60 to approximately $650 \mathrm{pmol} / 1$ increased IRS- 1 tyrosine phosphorylation sixfold over basal concentrations in control subjects, whereas no significant increase was noted in Type II diabetic subjects (Fig.4). The reduced IRS-1 phosphorylation in skeletal muscle from Type II diabetic patients was not related to changes in IRS-1 protein content [77, 89]. Physiological hyperinsulinaemia increased PI 3-kinase activity

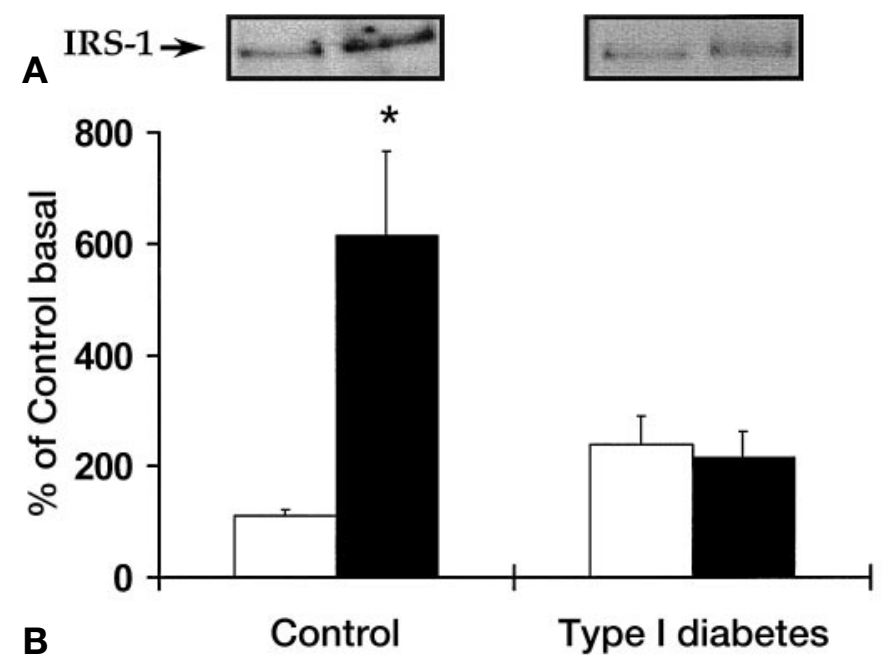

Fig. 4A, B. Insulin-receptor substrate-1 tyrosine phosphorylation in human skeletal muscle. Muscle biopsy specimens were obtained from healthy and Type II diabetic subjects, before and after euglycaemic hyperinsulinaemic clamp. A shows basal or insulin-stimulated IRS-1 tyrosine phosphorylation in skeletal muscle from control and Type II diabetic subjects. B shows tyrosine phosphorylation of IRS-1 assessed in basal ( $\square$ ) or insulin-stimulated $(\square)(\sim 700 \mathrm{pmol} / \mathrm{l})$ skeletal muscle [77]. Reproduced from Björnholm et al. [77] with permission from $\mathrm{Di}$ abetes

in control muscle twofold, whereas no increase was noted in skeletal muscle from Type II diabetic subjects. Furthermore, 3-O-methylglucose transport stimulated by insulin in vitro was $40 \%$ lower in isolated muscle from Type II diabetic patients. These findings couple both reduced insulin-stimulated IRS-1 tyrosine phosphorylation and PI 3-kinase activity to impaired insulin-stimulated glucose transport in skeletal muscle from lean to moderately obese Type II diabetic subjects. Thus, in addition to reduced IR-kinase activity $[79,87,90]$, defects in insulin-signalling through IRS-1 and PI 3-kinase [77, $81,91]$ could contribute to impaired glucose transport $[3,60,70,71]$ and reduced insulin-stimulated GLUT4 translocation in muscle from Type II diabetic patients [92]. Future studies performed in first-degree relatives of Type II diabetic patients could show whether these signalling defects are a primary cause of insulin resistance or secondary to an altered metabolic milieu. 


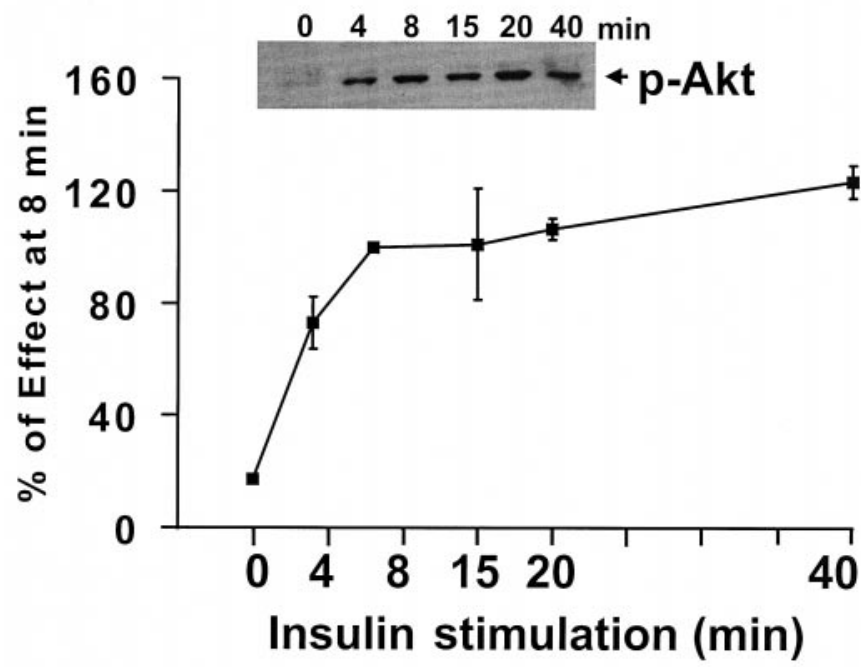

Fig.5. Time course of Akt phosphorylation. Isolated vastus lateralis skeletal muscle from healthy subjects incubated in vitro in the absence or presence of $60 \mathrm{nmol} / 1$ insulin for 4 to $40 \mathrm{~min}$. Muscle lysates were subjected to SDS-polyacrylamide gel electrophoresis and immunoblotted with a phosphospecific polyclonal anti-Akt antibody as described [74]. Results are presented as means \pm SEM

Defects in intermediate steps in the insulin-signalling cascade. The serine/threonine kinase Akt is stimulated by receptor tyrosine kinases and is a downstream target of PI 3-kinase [32-34, 93], through activation of the phosphatidylinositol 3,4,5-trisphosphate-dependent protein kinase [94]. Akt is stimulated in human skeletal muscle in response to in vitro [71, 95] or in vivo [91] insulin exposure. In human skeletal muscle, Akt is rapidly activated by insulin within $8 \mathrm{~min}$ (Fig. 5), and activation is sustained during $40 \mathrm{~min}$ of insulin stimulation. Insulin-stimulated (60 $\mathrm{nmol} / \mathrm{l}$ ) Akt phosphorylation is reduced in skeletal muscle from Type II diabetic patients compared with control subjects [71]. At lower, more physiological insulin concentrations, Akt activity is, however, similar between control and Type II diabetic subjects. Akt phosphorylation was determined in skeletal muscle after insulin stimulation in vivo (Fig. 6). A modification of the hyperinsulinaemic clamp procedure was used in conjunction with a needle biopsy to obtain vastus lateralis muscle. Muscle biopsy specimens were obtained under local anaesthesia, $30 \mathrm{~min}$ after a glucose-priming period. Thereafter, a bolus injection of insulin was given $\left(18.4 \mathrm{nmol} \times \mathrm{kg}^{-1} \times \mathrm{min}^{-1}\right)$ for $4 \mathrm{~min}$ and hyperinsulinaemia was maintained by a continuous insulin infusion $\left(5.8 \mathrm{nmol} \times \mathrm{kg}^{-1} \times\right.$ $\mathrm{min}^{-1}$ ). At $40 \mathrm{~min}$ after the onset of the insulin infusion, a second biopsy specimen was obtained. Serum insulin concentrations at the time of the muscle biopsy were $40 \pm 4$ and $118 \pm 36 \mathrm{pmol} / \mathrm{l}$ under basal conditions $(p=0.07)$ and $1774 \pm 253$ and $2080 \pm 242 \mathrm{pmol} / \mathrm{l}$ (NS) under insulin-stimulated conditions for four control and five Type II diabetic subjects, respective-
Control Diabetic

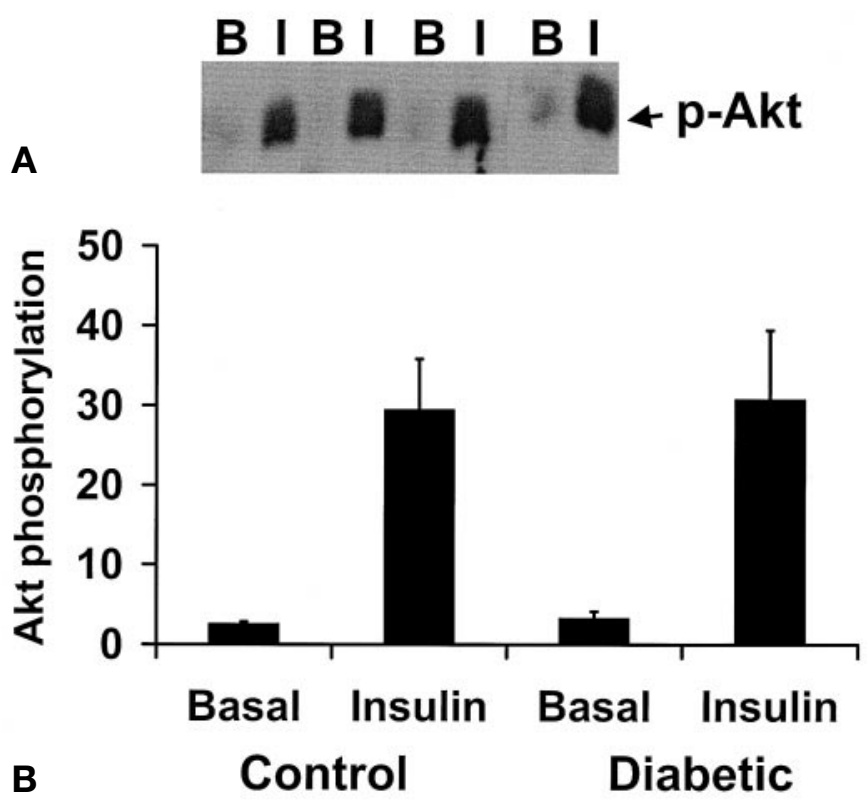

Fig. 6A,B. Phosphorylation of Akt in response to in vivo insulin infusion. Vastus lateralis muscle biopsy specimens were obtained from healthy or Type II diabetic subjects before (B) or after a $40 \mathrm{~min}$ insulin infusion (I). Muscle lysates were analysed for Akt phosphorylation as described in Fig. 5. A Representative immunoblot. B Results are presented as means \pm SEM

ly. When skeletal muscle was stimulated in vivo by means of a hyperinsulinaemic clamp, Akt phosphorylation was similar between moderately overweight Type II diabetic patients and control subjects (Fig. 6). These findings are consistent with a previous report showing normal insulin action on Akt in obese subjects with or without Type II diabetes [91]. Furthermore, insulin-mediated activation of the three Akt isoforms was normal in skeletal muscle from obese Type II diabetic patients despite reduced IRS1-associated and IRS-2-associated PI 3-kinase activity [91]. Thus insulin resistance at the level of Akt does not appear to account for the impaired insulin stimulation of glucose transport noted in skeletal muscle from obese or Type II diabetic subjects.

Several studies provide evidence that alterations in the distribution of PKC isoforms occur in skeletal muscle from diabetic animals [96]. Some of these changes could be long-term, occurring in response to increased concentrations of glucose, insulin, or lipids. Changes in $\mathrm{PKC} \theta$ and $\mathrm{PKC} \varepsilon$ are evident in skeletal muscle from dietary-induced (high-fat fed) insulinresistant rats and these changes seem to be related to muscle triglyceride and diglyceride concentrations [97]. In the non-obese Goto-Kakizaki (GK) diabetic rat [98], PKC enzyme activity and the content of $\mathrm{PKC} \alpha, \mathrm{PKC} \beta, \mathrm{PKC} \varepsilon$ and $\mathrm{PKC} \delta$ is increased in membrane fractions and decreased cytosolic fractions of 
soleus muscle, relative to control Wistar rats. In addition, $\mathrm{PKC} \vartheta$ content in GK soleus muscles is decreased in both membrane and cytosol fractions, whereas $\mathrm{PKC}-\zeta$ content is not changed in either fraction. Changes in the distribution or expression or both of the PKC isoforms could occur in response to a short-term increase in glucose or lipid availability. Short-term exposure of isolated soleus muscle from Wistar rats to $25 \mathrm{mmol} / \mathrm{l}$ glucose increased the total membrane content of $\mathrm{PKC} \beta_{2}$ and $\mathrm{PKC} \zeta$ threefold and 1.4-fold, respectively, whereas membrane content of PKC $\alpha, \beta_{1}, \delta, \varepsilon$ and $\vartheta$ were unchanged [99]. The effect of these glucose-induced changes in PKC distribution on intracellular events in skeletal muscle is, however, currently not known. High extracellular glucose concentrations have been reported to inhibit insulin action by inducing serine phosphorylation of the insulin receptor through a PKC-mediated mechanism [100]. In addition, increases in circulating concentrations of non-esterified fatty acids (NEFA) lead to an activation of $\mathrm{PKC} \vartheta$ and a reduction in insulinstimulated PI 3-kinase activity associated with IRS-1[101]. Increased membrane-associated PKC activity leads to reduced insulin action in freshly isolated circulating mononuclear cells, liver and skeletal muscle in obese people with and without Type II diabetes [102, 103]. Because hyperglycaemia or increased concentrations of NEFA or both can have a pronounced effect on whole-body glucose homeostasis, activation of the PKCs by high glucose or increased concentrations of NEFA could be linked to impaired insulin signal transduction and reduced glucose transport in Type II diabetic patients.

Defects in GLUT4 traffic. Defects in the GLUT4 translocation machinery could contribute to impaired insulin-stimulated, whole-body glucose uptake [82, $83,92]$. This could be a consequence of impaired insulin signal transduction or a defect(s) in GLUT4 traffic or both. In morbidly obese people, the reduced insulin-stimulated glucose transport could also be explained in part from reduced GLUT4 expression in skeletal muscle [104]. In lean Type II diabetic patients, total GLUT4 protein expression in skeletal muscle is, however, not altered [105, 106]. Thus, impaired function or distribution of GLUT4 probably accounts for reduced glucose uptake [92]. Nevertheless, GLUT4 has an abnormal subcellular localisation in skeletal muscle from insulin-resistant subjects without or with overt Type II diabetes [82]. This suggests that defects in GLUT4 trafficking and translocation are a cause of insulin resistance in skeletal muscle. Thus, insulin resistance could be partly due to a failure of GLUT4 vesicles to translocate, dock or fully fuse with the plasma membrane (Fig. 2).

In rodents the reduced insulin-stimulated glucose transport in soleus muscle observed after high-fat feeding [62], can be accounted for by a decrease

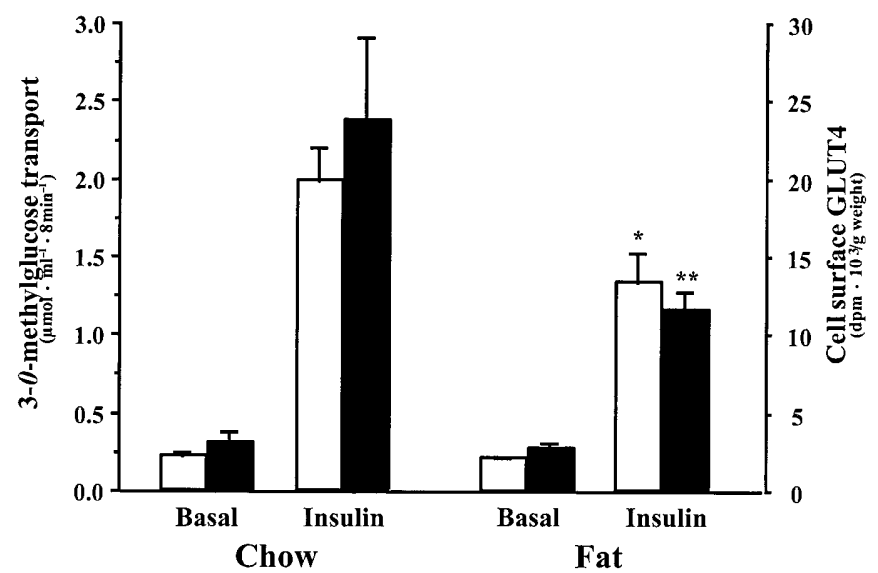

Fig. 7. Correlation between cell-surface GLUT4 and glucose transport. Comparison between basal and insulin-stimulated $(2000 \mu \mathrm{U} / \mathrm{ml}) 3-O$-methylglucose transport $(\square)$ and cell-surface GLUT4 content as assessed by photolabelling ( $\square$ ) in isolated soleus muscle from mice fed a high-fat or standard rodent chow. $* p<0.05, * * p<0.01$ fat-fed vs chow-fed mice. Reproduced from Zierath et al. [62] with permission from Diabetes

in cell surface GLUT4 content as assessed by exofacial labelling with ATB $\left[2-{ }^{3} \mathrm{H}\right] \mathrm{BMPA}$ bis-mannose (Fig. 7). Thus, insulin resistance associated with highfat feeding results from impaired insulin-induced translocation or fusion of GLUT4 with the plasma membrane or both. This could result from an acquired defect in the activation of PI 3-kinase by insulin because PI 3-kinase associated with IRS-1 is also reduced in skeletal muscle after high-fat feeding [62]. In the same study, okadaic acid-stimulated glucose transport was, however, reduced in skeletal muscle after high-fat feeding. Because okadaic acid seems to activate glucose transport at a point downstream from PI 3-kinase [107], this compound could also affect proteins involved in the traffic of GLUT4 vesicles to the plasma membrane. Thus, reduced insulin-stimulated glucose transport could result from defects in early components of the insulin signalling cascade, as well as from signalling defects which alter GLUT4 exocytosis from an intracellular compartment to the plasma membrane. A critical undefined, downstream signalling intermediate could, however, be severely impaired in diabetic skeletal muscle and this could account for the reduced glucose transport.

\section{Hyperglycaemia as a negative regulator of glucose transport}

Chronic hyperglycaemia is a characteristic feature of Type II diabetes and could be one factor leading to the development of peripheral insulin resistance in skeletal muscle. In diabetic rodents, substantial evidence has accumulated to suggest that chronic hyperglycaemia can directly contribute to the development 
of peripheral insulin resistance $[67,68,108-110]$. The precise sensing mechanism by which hyperglycaemia leads to impaired insulin action is not fully known. The effects of hyperglycaemia are mediated in part by metabolites of the hexosamine pathway. Increased biosynthetic activity within the hexosamine pathway is associated with the development of insulin resistance [110]. In partially pancreatectomised diabetic rats, correction of hyperglycaemia by phlorizin treatment restored insulin-stimulated glucose transport in isolated adipocytes and improved whole-body insulin sensitivity [108-110]. In Type II diabetic patients, restoration of euglycaemia after weight loss $[111,112]$, sulphonylurea treatment $[113,114]$ or insulin therapy $[115,116]$ enhances insulin sensitivity in adipocytes and skeletal muscle. We have shown that insulinstimulated glucose transport is fully restored to normal in isolated skeletal muscle from Type II diabetic patients after a 2 -h exposure in vitro to media containing low $(4 \mathrm{mmol} / \mathrm{l})$, but not high $(8 \mathrm{mmol} / \mathrm{l})$ glucose [73]. Furthermore, restoration of blood glucose concentrations in patients with poorly controlled Type I diabetes [117] is associated with improved insulin-mediated, whole-body glucose uptake. Although restoration of glycaemia is associated with improved insulin action on glucose uptake, the extent to which restoring glycaemia to normal can improve impaired insulin signalling in skeletal muscle from insulin-resistant animals or humans is not fully known.

The molecular mechanism by which restoration of glycaemia improves insulin action in skeletal muscle could involve improved insulin signal transduction at the level of IRS-1, PI 3-kinase, Akt kinase, or GLUT4 translocation. Functional defects have been reported at each of these steps in skeletal muscle from diabetic rodents $[30,64,69,84-86]$ and humans $[71,77,78,91,118]$. Effects of hyperglycaemia on insulin signal transduction and glucose transport have been assessed in the spontaneously diabetic GK rat, a non-obese model of Type II diabetes [67, 68]. This animal model of diabetes is developed by selective breeding of glucose-intolerant Wistar rats over several generations [119]. Restoration of glycaemia by phlorizin treatment in GK rats partly restored glucose tolerance and fully restored insulin-stimulated signal transduction at the level of Akt and glucose transport $[67,68]$. The improvements in insulin action were completely disassociated from insulin action at the level of PI 3-kinase [68]. Similarly, incubation of non-diabetic rat soleus muscle with $25 \mathrm{mmol} / \mathrm{l}$ glucose has been found to inhibit insulin action on glycogen synthase and Akt but not PI 3-kinase [120]. Thus, it could be that full activation of PI 3-kinase is not necessary for full activation of glucose transport. Furthermore, there are probably other signalling pathways mediating insulin action, glucose transport and glycogen synthesis. Collectively, these data are consistent with the notion that chronic hyperglycaemia has deleterious effects on the intermediate and final components of the insulin signalling pathways in skeletal muscle.

\section{Muscle contraction as a positive regulator of glucose transport}

In skeletal muscle, glucose transport can be activated by at least two separate pathways, one stimulated by insulin, insulin mimicking agents and insulin-like growth factors, and one activated by muscle contraction/exercise, hypoxia [2, 3, 23-25, 62, 121-126]. Phosphatidylinositol 3-kinase is involved in insulinstimulated but not contraction-stimulated glucose transport and GLUT4 translocation [23-25]. Whereas, $5^{\prime}$-AMP-activated kinase $[127,128]$, as well as increases in cytoplasmic calcium concentrations [129, 130], could be involved in the contraction response because they both lead to insulin-independent increases in glucose transport. Reduced glucose transport activity in skeletal muscle from Type II diabetic patients can occur from defects in insulin signalling or GLUT4 vesicle traffic to the plasma membrane. A means of addressing whether a trafficking impairment contributes to the insulin resistance in Type II diabetes is to examine the translocation of GLUT4 in response to stimuli other than insulin. Exposure of isolated skeletal muscle to hypoxia leads to an insulin-independent increase in glucose transport and GLUT4 translocation $[62,125,126]$. Hypoxia and exercise induce GLUT4 recruitment to the cell surface and increase glucose transport [62, 125, 126, 131]. Therefore, perturbing the muscle contraction/hypoxia pathway is a method to show whether the insulin resistance associated with Type II diabetes is limited to the insulin-signalling cascade or is a consequence of generalised resistance in the mechanism(s) involved in GLUT4 translocation. In skeletal muscle from diabetic rats, muscle contraction stimulates glucose transport despite severe insulin resistance of the glucose transport process [2, 121, 132, 133]. Even in muscle from animals with dietary-induced insulin resistance, perturbing the muscle contraction pathway with in vitro hypoxia or through incubation with $\mathrm{W}-7$, fully activates glucose transport [62]. Thus, activation of the muscle contraction pathway is a powerful stimulator of glucose transport and GLUT4 translocation and could be one alternative means to activate glucose transport in insulin-resistant conditions.

\section{Exercise as a therapeutic intervention in the management of Type II diabetes}

For the well being of the patient and from a public health care perspective, effective intervention strategies are essential to develop to reduce the incidence 
of Type II diabetes and the resulting complications. In healthy, non-diabetic people, long-term exercise has very little effect on blood glucose concentrations. In healthy subjects and Type II diabetic patients, short-term exercise has, however, long been known to increase glucose uptake in skeletal muscle [134]. Recently, short-term exercise has been shown to increase glucose transport in isolated skeletal muscle from healthy subjects (Fig. 8). In human skeletal muscle, exercise is a potent stimulator of glucose transport [3]. The last observation provides direct evidence that in humans, exercise is a potent regulator of glucose transport activity [3]. Furthermore, the combined effect of insulin and exercise are additive on glucose transport activity [3], a finding which is consistent with studies using isolated rat epitrochlearis muscle [121, 133].

Effects of short-term exercise on glucose transport. Short-term exercise could be one strategy to improve glucose homeostasis in Type II diabetic patients. For example, exercise of moderate to heavy intensity is usually associated with a decrease in blood glucose concentration in Type II diabetic patients. Thus, a single bout of exercise often leads to a decrease in plasma glucose concentrations [135-137] and this persists into the post-exercise period $[135,138]$. The effect of exercise in lowering blood glucose in Type II diabetic patients could be explained by the insulin-independent activation of glucose transport and GLUT4 by exercise [132] as well as by increased insulin sensitivity [139]. Activation of this alternative pathway could be one way to improve glucose homeostasis by increasing glucose uptake and lowering blood glucose concentrations in Type II diabetic patients. A preliminary report provides evidence that $45-60 \mathrm{~min}$ of cycle exercise at $60-70 \% \mathrm{VO}_{2 \max }$ led to a similar mean increase in plasma membrane GLUT4 content ( $\sim 70 \%$ above basal contents) in skeletal muscle from healthy subjects and Type II diabetic patients [140]. Although the plasma membrane content was about $30 \%$ lower in the Type II diabetic patients at rest and after exercise, this difference was not statistically significant. These studies highlight the potential importance of physical exercise in maintaining glucose homeostasis in Type II diabetic patients.

Effects of exercise training on glucose transport. Improvements in insulin sensitivity through regular exercise could overcome defects in insulin signal transduction noted in muscle from Type II diabetic patients. Importantly, exercise training improves glucose tolerance and insulin action in insulin-resistant humans $[141,142]$. The molecular mechanism for enhanced glucose uptake with long-term exercise training could be related in part to increased expression and activity of key proteins involved in the regulation of glucose uptake and metabolism in skeletal muscle. Molecular

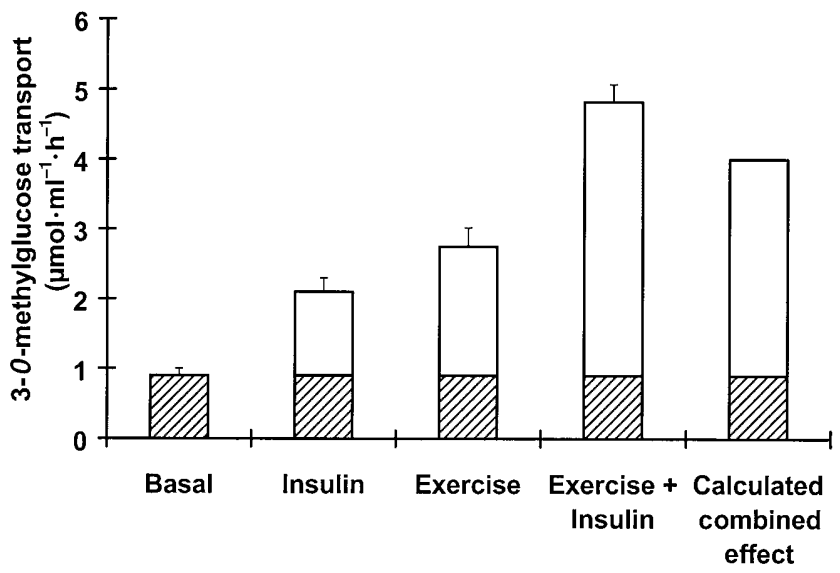

Fig. 8. Exercise-induced increase in glucose transport in human skeletal muscle. The separate or combined effects of exercise (bicycle exercise to exhaustion) or maximum insulin $(1000 \mu \mathrm{U} / \mathrm{ml})$ on $3-O$-methylglucose transport in human skeletal muscle. Muscle biopsy specimens were obtained from vastus lateralis muscle. Reproduced from Zierath [3] with permission from Acta Physiologica Scandinavica

candidates for improved glucose homeostasis in connection with exercise include GLUT4 [142-149], hexokinase (HK) II [149-151] and glycogen synthase [149, 152-154]. Muscle contraction/exercise directly leads to the activation of several mitogen-activated protein (MAP) kinase cascades [155-159]. The MAP kinase family forms a major and ubiquitous intracellular signalling system, related to cell growth, differentiation and survival [160]. Extracellular-regulated kinase $1 / 2$ phosphorylation and p38 MAP kinase phosphorylation are increased in response to forced contraction of isolated rat skeletal muscle by electrical stimulation [159] and through a more physiological means to achieve muscle contraction by short-term (30 min) bicycle exercise in humans [158]. Activation of the MAP kinase cascade could provide a mechanism by which muscle contraction alters gene expression. Clearly additional studies are warranted to link the MAP kinase signalling cascade to changes in protein expression in skeletal muscle after exercise.

Glucose transporter 4 has been identified as a key player in the regulation of glucose transport. Thus, an exercise training-induced overexpression of GLUT4 could improve glucose transport in diabetic muscle. A direct connection between increased GLUT4 protein expression and increased basal and insulin-stimulated glucose transport and metabolism has been made from GLUT4-transgenic mouse models [126, 161-164]. Several groups have successfully shown overexpression of GLUT4 in skeletal muscle can prevent impaired whole-body glucose homeostasis associated with various states of insulin resistance. For example, modest overexpression (twofold) of GLUT4 in heart, skeletal muscle and adipose tis- 
sue in transgenic mice prevented the impairment of glycaemic control and the accompanying hyperglycaemia caused by high-fat feeding [165]. Furthermore, GLUT4 overexpression in skeletal muscle considerably improved whole-body insulin action and reduced blood glucose concentrations in streptozotocin-induced diabetic [166] and homozygous genetically predisposed diabetic $(d b / d b)$ mice [167]. Although glucose transport is generally believed to be rate limiting for insulin-mediated glucose metabolism in muscle $[55,168]$, under hyperglycaemic or hyperinsulinaemic conditions, the rate-limiting step could shift beyond transport [169]. Note, transgenic overexpression of HK II, the predominant HK isoform in skeletal muscle, leads to increased basal and insulinstimulated glucose uptake [170].

Perturbations which alter neuromuscular activity patterns, including physical exercise or long-term electrical stimulation, are physiological means to achieve protein overexpression of key genes involved in maintaining glucose homeostasis [142-149]. Exercise training leads to a twofold to fourfold increase in GLUT4 protein expression in human skeletal muscle and improves glucose intolerance and insulin action $[142,146,148,149,171]$. Muscle contraction improves insulin action on whole-body and cellular glucose uptake in cervical-cord-injured people through a major increase in protein expression of key genes involved in the regulation of glucose metabolism [149]. Furthermore, exercise training leads to an increase in basal and insulin-stimulated glucose transport in human skeletal muscle [149]. Nevertheless, adaptive responses to prior exercise are not limited to changes in GLUT4 expression, as increased expression or function of proteins involved in insulin-signal transduction could occur [172, 173]. For example, insulin-stimulated receptor phosphorylation, IRS-1 tyrosine phosphorylation and PI 3-kinase activity associated with IRS-1 are increased $16 \mathrm{~h}$ after 1 or 5 days of swimming training in rats [173]. Future studies are warranted to fully ascertain the extent to which the exercise traininginduced increase in GLUT4 protein content can improve defects in glucose transport in skeletal muscle from Type II diabetic patients. Collectively, these studies underscore the importance of exercise training as a therapeutic strategy to maintain whole-body glucose homeostasis. Importantly, they provide molecular evidence that exercise leads to changes in activity and expression of proteins known to regulate cell growth and glucose homeostasis.

Acknowledgements. The authors thank Y. Kawano for allowing them to use Fig. 2. Cited work from the authors' laboratory was supported by grants from the Swedish Medical Research Council (12669, 12679, 9517, 12211), Thurings Foundation, Magnus Bergwalls Foundation, Tore Nilsons Foundation, the Novo-Nordisk Foundation, Harald and Greta Jeanssons Foundation, the Swedish Diabetes Association and the Foundation for Scientific Studies of Diabetology.

\section{References}

1. Shepherd PR, Kahn BB (1999) Glucose transporters and insulin action. N Engl J Med 341: 248-257

2. Wallberg-Henriksson H, Holloszy JO (1985) Activation of glucose transport in diabetic muscle: Responses to contraction and insulin. Am J Physiol 249: C233-C237

3. Zierath JR (1995) In vitro studies of human skeletal muscle. Hormonal and metabolic regulation of glucose transport. Acta Physiol Scand 155: 1-96

4. Manson JE, Spelsberg A (1995) Reduction in risk factors of coronary heart disease and diabetes. In: Ruderman N, Devlin J (eds) The Health Professionals Guide to Diabetes and Exercise. The American Diabetes Association, Alexandria, p 51-58

5. Arner P, Pollare T, Lithell H (1991) Different aetiologies of Type II (non-insulin-dependent) diabetes mellitus in obese and nonobese subjects. Diabetologia 34: 483-487

6. Kelley DE, Mokan M, Mandarino LJ (1993) Metabolic pathways of glucose in skeletal muscle of lean NIDDM patients. Diabetes Care 16: 1158-1166

7. DeFronzo RA (1988) The Triumvirate: $\beta$-cell, muscle or liver. A collusion responsible for NIDDM. Diabetes 37: 667-687

8. DeFronzo RA, Jocot E, Jequier E, Maeder E, Wahren J, Felber JP (1981) The effect of insulin on the disposal of intravenous glucose. Diabetes 30: 1000-1007

9. DeFronzo RA, Gunnarsson R, Björkman O, Olsson M, Wahren J (1985) Effects of insulin on peripheral and splanchnic glucose metabolism in non-insulin-dependent (Type II) diabetes mellitus. J Clin Invest 76: 149-155

10. DeFronzo RA, Tobin JD, Anders R (1979) Glucose clamp technique: a model for quantifying insulin secretion and resistance. Am J Physiol 237: E214-E223

11. Nuutila P, Koivisto VA, Knuuti J et al. (1992) Glucosefree fatty acid cycle operates in human heart and skeletal muscle in vivo. J Clin Invest 89: 1767-1774

12. Eriksson J, Koranyi L, Bourey R et al. (1992) Insulin resistance in Type II (non-insulin-dependent) diabetic patients and their relatives is not associated with a defect in the expression of the insulin-responsive glucose transporter (GLUT4) gene in human skeletal muscle. Diabetologia 35: $143-147$

13. Shulman GI, Rothman DL, Jue T, Stein P, DeFronzo RA, Shulman RG (1990) Quantitation of muscle glycogen synthesis in normal subjects and subjects with non-insulin-dependent diabetes by $13 \mathrm{C}$ nuclear magnetic resonance spectroscopy. N Engl J Med 322: 223-228

14. Henriksen JE, Alford F, Handberg A et al. (1994) Increased glucose effectiveness in normoglycemic but insulin-resistant relatives of patients with non-insulin-dependent diabetes mellitus. J Clin Invest 94: 1196-1204

15. Groop L, Bonadonna RC, Del Prato S et al. (1989) Glucose and free fatty acid metabolism in non-insulin-dependent diabetes mellitus: Evidence for multiple sites of insulin resistance. J Clin Invest 84: 205-213

16. Bonadonna RC, Del Prato S, Bonora E et al. (1996) Roles of glucose transport and glucose phosphorylation in muscle insulin resistance of NIDDM. Diabetes 45: 915-925

17. Kahn CR (1994) Insulin action, diabetogenes, and the cause of Type II diabetes. Diabetes 43: 1066-1084

18. White MF, Kahn CR (1994) The insulin signaling system. J Biol Chem 269: 1-4

19. Virkamäki A, Ueki K, Kahn CR (1999) Protein-protein interactions in insulin signaling and the molecular mechanisms of insulin resistance. J Clin Invest 103: 931-943 
20. Araki E, Lipes MA, Patti ME et al. (1994) Alternative pathway of insulin signalling in mice with targeted disruption of the IRS-1 gene. Nature 372: 186-190

21. Whithers DJ, Gutierrez JS, Towery H et al. (1998) Disruption of IRS-2 causes type 2 diabetes in mice. Nature 391: 900-904

22. White MF (1998) The insulin signalling system: a network of docking protein that mediate insulin action. Mol Cell Biochem 182: 3-11

23. Yeh J-I, Gulve EA, Rameh L, Birnbaum MJ (1995) The effects of wortmannin on rat skeletal muscle. J Biol Chem 270: 2107-2111

24. Lund S, Holman GD, Schmitz O, Pedersen O (1995) Contraction stimulates translocation of glucose transporter GLUT4 in skeletal muscle through a mechanism distinct from that of insulin. Proc Natl Acad Sci USA 92: $5817-5821$

25. Lee AD, Hansen PA, Holloszy JO (1995) Wortmannin inhibits insulin-stimulated but not contraction-stimulated glucose transport activity in skeletal muscle. FEBS Lett 361: 51-54

26. Inoue G, Cheatham B, Emkey R, Kahn CR (1998) Dynamics of insulin signaling in 3T3-L1 adipocytes. Differential compartmentalization and trafficking of insulin receptor substrate (IRS)-1 and IRS-2. J Biol Chem 273: 11548-11555

27. Clark SF, Martin S, Carozzi AJ, Hill MM, James DE (1998) Intracellular localization of phosphatidylinositide 3-kinase and insulin receptor substrate-1 in adipocytes: potential involvement of a membrane skeleton. J Cell Biol 140: 1211-1225

28. Inukai K, Anai M, Van Breda E et al. (1996) A novel 55$\mathrm{kDa}$ regulatory subunit for phosphatidylinositol 3-kinase structurally similar to p55PIK is generated by alternative splicing of the p85 $\alpha$ gene. J Biol Chem 271: 5317-5320

29. Inukai K, Funaki M, Ogihara T et al. (1997) p85a gene generates three isoforms of regulatory subunit for phosphatidylinositol 3-kinase (PI 3-kinase) p50 $\alpha$, p55 $\alpha$, and p85 $\alpha$, with different response to insulin. J Biol Chem 272: 7873-7882

30. Anai M, Funaki M, Ogihara T et al. (1998) Altered expression levels and impaired steps in the pathway to phosphatidylinosital 3-kinase activation via insulin receptor substrates 1 and 2 in Zucker Fatty rats. Diabetes 47: 13-23

31. Shepherd PR, Navé B, Rincon J et al. (1997) Differential regulation of phosphoinositide 3-kinase adapter subunit variants by insulin in human skeletal muscle. J Biol Chem 272: 19000-19007

32. Kohn AD, Kovacina KS, Roth RA (1995) Insulin stimulates the kinase activity of RAC-PK, a pleckstrin homology domain containing ser/thr kinase. EMBO J 14: 4288-4295

33. Burgering BMT, Coffer PJ (1995) Protein kinase B (cAkt) in phosphatidylinositol-3-OH kinase signal transduction. Nature 376: 599-602

34. Didichenko SA, Tilton B, Hemmings BA, Ballmer-Hofer K, Thelen M (1996) Constitutive activation of protein kinase $\mathrm{B}$ and phosphorylation of $\mathrm{p} 47^{\text {phox }}$ by a membranetargeted phosphoinositide 3-kinase. Curr Biol 6: 1271-1278

35. Kohn AD, Summers SA, Birnbaum MJ, Roth RA (1996) Expression of a constitutively active Akt Ser/Thr kinase in 3T3-L1 adipocytes stimulates glucose uptake and glucose transporter 4 translocation. J Biol Chem 271: 31372-31378

36. Tanti J-F, Grillo S, Grémeaux T, Coffer PJ, Van Obberghen E, Le Marchand-Brustel Y (1997) Potential role of protein kinase B in glucose transporter 4 translocation in adipocytes. Endocrinology 138: 2005-2010

37. Hajduch E, Alessi DR, Hemmings BA, Hundal HS (1998) Constitutive activation of protein kinase $\mathrm{B} \alpha$ by membrane targeting promotes glucose and system A amino acid transport, protein synthesis, and inactivation of glycogen synthase kinase 3 in L6 muscle cells. Diabetes 47: 1006-1013

38. Ueki K, Yamamoto-Honda R, Kaburagi Y et al. (1998) Potential role of protein kinase $\mathrm{B}$ in insulin-induced glucose transport, glycogen synthesis, and protein synthesis. J Biol Chem 273: 5315-5322

39. Wang Q, Somwar R, Bilan PJ et al. (1999) Protein kinase B/Akt participates in GLUT4 translocation by insulin in L6 myoblasts. Mol Cell Biol 19: 4008-4018

40. Kitamura T, Ogawa W, Sakaue H et al. (1998) Requirement for activation of the serine-threonine kinase Akt (Protein kinase B) in insulin stimulation of protein synthesis but not glucose transport. Mol Cell Biol 18: 3708-3717

41. Nishizuka Y (1995) Protein kinase C and lipid signaling for sustained cellular responses. FASEB J 9: 484-496

42. Dekker LV, Parker PJ (1994) Protein kinase-C: a question of specificity. Trends Biochem Sci 19: 73-77

43. Hug H, Sarre TF (1993) Protein kinase C isoenzymes: divergence in signal transduction? Biochem J 291: 329-343

44. Hansen PA, Corbett JA, Holloszy JO (1997) Phorbol esters stimulate muscle glucose transport by a mechanism distinct from the insulin and hypoxia pathways. Am J Physiol 273: E28-E36

45. Standaert ML, Galloway L, Karnam P, Bandyopadhyay G, Moscat J, Farese RV (1997) Protein kinase C- as a downstream effector of phosphatidylinositol 3-kinase during insulin stimulation in rat adipocytes. Potential role in glucose transport. J Biol Chem 272: 30075-30082

46. Nakanishi H, Brewer KA, Exton JH (1993) Activation of the $\zeta$ isoenzyme of protein kinase $\mathrm{C}$ by phosphatidylinositol 3,4,5-trisphosphate. J Biol Chem 268: 13-16

47. Kotani K, Ogawa W, Matsumoto M et al. (1998) Requirement of atypical protein kinase $\mathrm{C} \lambda$ for insulin stimulation of glucose uptake but not for Akt activation in 3T3-L1 adipocytes. Mol Cell Biol 18: 6971-6982

48. Bandyopadhyay G, Standaert ML, Zhao L et al. (1997) Activation of protein kinase $\mathrm{C}(\alpha, \beta$, and $\zeta)$ by insulin in 3T3/L1 cells: Transfection studies suggest a role for PKC- $\zeta$ in glucose transport. J Biol Chem 272: 2551-2558

49. Hirshman MF, Goodyear LJ, Wardzala LJ, Horton ED, Horton ES (1990) Identification of an intracellular pool of glucose transporters from basal and insulin-stimulated rat skeletal muscle. J Biol Chem 265: 987-991

50. Ploug T, van Deurs B, Ai H, Cushman SW, Ralston E (1998) Analysis of GLUT4 distribution in whole skeletal muscle fibers: identification of distinct storage compartments that are reduced by insulin and muscle contractions. J Cell Biol 142: 1429-1446

51. Gumà A, Zierath JR, Wallberg-Henriksson H, Klip A (1995) Insulin induces translocation of GLUT-4 glucose transporters in human skeletal muscle. Am J Physiol 268: E613-E622

52. James DE, Strube MM, Mueckler MM (1989) Molecular cloning and characterization of an insulin-regulatable glucose transporter. Nature 338: 83-87

53. Charron MJ, Brosius FC, Alper SL, Lodish HL (1989) A glucose transport protein expressed predominately in insulin-sensitive tissues. Proc Natl Acad Sci USA 86: 2535-2539 
54. Birnbaum MJ (1989) Identification of a novel gene encoding an insulin-responsive glucose transporter protein. Cell 57: $305-315$

55. Ren JM, Marshall BA, Gulve EA et al. (1993) Evidence from transgenic mice that glucose transport is rate limiting for glycogen deposition and glycolysis in skeletal muscle. J Biol Chem 268: 16113-26115

56. Treadway JL, Hargrave MD, Nardone NA et al. (1994) Enhances peripheral glucose utilization in transgenic mice expressing the human GLUT4 gene. J Biol Chem 269: 29956-29961

57. Marshall BA, Mueckler MM (1994) Differential effects of GLUT1 or GLUT4 overexpression on insulin responsiveness in transgenic mice. Am J Physiol 267: E738-E744

58. Holman GD, Kasuga M (1997) From receptor to transporter: Insulin signalling to glucose transport. Diabetologia 40: 991-1003

59. Dohm GL, Tapscott EB, Pories WJ et al. (1988) An in vitro human skeletal muscle preparation suitable for metabolic studies. Decreased insulin stimulation of glucose transport in muscle from morbidly obese and diabetic subjects. J Clin Invest 82: 486-494

60. Andréasson K, Galuska D, Thörne A, Sonnenfeld T, Wallberg-Henriksson H (1991) Decreased insulin-stimulated 3-O-methylglucose transport in in vitro incubated muscle strips from type II diabetic subjects. Acta Physiol Scand 142: 255-260

61. Narahara HT, Ozand P (1963) Studies of tissue permeability. IX. The effect of insulin on the penetration of 3-methylglucose- ${ }^{3} \mathrm{H}$ in frog muscle. J Biol Chem 238: 40-49

62. Zierath JR, Houseknecht K, Gnudi L, Kahn BB (1997) High fat feeding impairs insulin-stimulated GLUT4 recruitment in muscle via an early insulin signaling defect. Diabetes 46: 215-223

63. Wallberg-Henriksson H (1986) Insulin treatment normalizes decreased glucose transport capacity in streptozotocin-diabetic rats. Acta Physiol Scand 128: 647-659

64. Heydrick SJ, Gautier N, Olichon-Berthe C, Van Obberghen E, Le Marchand-Brustel Y (1995) Early alteration of insulin stimulation of PI 3-kinase in muscle and adipocyte from gold thioglucose obese mice. Am J Physiol 268: E604-E612

65. Kraegen EW, James DE, Storlien LH, Burleigh KM, Crisholm DJ (1986) In vivo insulin resistance in individual peripheral tissues of the high fat fed rat: assessment by euglycaemic clamp plus deoxyglucose administration. Diabetologia 29: 192-198

66. Wallberg-Henriksson H, Zetan N, Henriksson J (1987) Reversibility of decreased insulin-stimulated glucose transport capacity in diabetic muscle with in vitro incubation. J Biol Chem 262: 7665-7671

67. Krook A, Kawano Y, Song XM et al. (1997) Improved glucose tolerance restores insulin-stimulated Akt kinase activity and glucose transport in skeletal muscle from diabetic Goto-Kakizaki (GK) rats. Diabetes 46: 2110-2114

68. Song XM, Kawano Y, Krook A et al. (1999) Muscle fibertype specific defects in insulin signal transduction to glucose transport in diabetic Goto-Kakizaki rats. Diabetes 48: $664-670$

69. Heydrick SJ, Jullien D, Gautier N et al. (1993) Defect in skeletal muscle phosphatidylinositol-3-kinase in obese insulin-resistant mice. J Clin Invest 91: 1358-1366

70. Galuska D, Nolte L, Zierath JR, Wallberg-Henriksson H (1994) Effect of metformin on glucose transport in isolated skeletal muscle obtained from Type II diabetic patients and healthy individuals. Diabetologia 37: 872-879
71. Krook A, Roth RA, Jiang XJ, Zierath JR, Wallberg-Henriksson H (1998) Insulin-stimulated Akt kinase activity is reduced in skeletal muscle from non-insulin-dependent diabetic subjects. Diabetes 47: 1281-1286

72. Cline GW, Petersen KF, Krssak M et al. (1999) Impaired glucose transport as a cause of decreased insulin-stimulated muscle glycogen synthesis in type 2 diabetes. $\mathrm{N}$ Engl J Med 341: 240-246

73. Zierath JR, Galuska D, Nolte L, Thörne A, SmedegaardKristensen J, Wallberg-Henriksson H (1994) Effects of glycemia on glucose transport in isolated skeletal muscle from patients with NIDDM: in vitro reversal of muscular insulin resistance. Diabetologia 37: 270-277

74. Strömmer L, Permert J, Arnelo U et al. (1998) Skeletal muscle insulin resistance after surgical trauma: insulin signaling and glucose transport. Am J Physiol 275: E351-E358

75. Lund S, Holman GD, Zierath JR et al. (1997) Effect of insulin on GLUT4 translocation and turnover rate in human skeletal muscle as measured by the exofacial bismannose photolabeling technique. Diabetes 46: 1965-1969

76. Holman GD, Kozka IJ, Clark AE et al. (1990) Cell-surface labeling of glucose transporter isoform GLUT4 by Bis-Mannose photolabel: correlation with stimulation of glucose transport in rat adipose cells by insulin and phorbol ester. J Biol Chem 265: 18172-18179

77. Björnholm M, Kawano Y, Lehtihet M, Zierath JR (1997) Insulin receptor substrate-1 phosphorylation and phosphatidylinositol 3-kinase activity are decreased in skeletal muscle from NIDDM subjects following in vivo insulin stimulation. Diabetes 46: 524-527

78. Goodyear LJ, Giorgino F, Sherman LA, Carey J, Smith RJ, Dohm GL (1995) Insulin receptor phosphorylation, insulin receptor substrate-1 phosphorylation and phosphatidylinositol 3-kinase activity are decreased in intact skeletal muscle strips from obese subjects. J Clin Invest 95: 2195-2204

79. Nolan JJ, Freidenberg G, Henery R, Reichart D, Olefsky JM (1994) Role of human skeletal muscle insulin receptor kinase in the in vivo insulin resistance of noninsulin-dependent diabetes mellitus and obesity. J Clin Endocrinol Metab 78: 471-477

80. Nyombia BL, Ossowski VM, Bogardus C, Mott DM (1990) Insulin-sensitive tyrosine kinase relationship with in vivo insulin action in humans. Am $\mathrm{J}$ Physiol 258: E964-E974

81. Krook A, Björnholm M, Galuska D et al. (2000) Characterization of signal transduction and glucose transport in skeletal muscle from type 2 diabetic patients. Diabetes 49: 284-292

82. Garvey WT, Maianu L, Zhu JH, Brechtel-Hook G, Wallace P, Baron AD (1998) Evidence for defects in the trafficking and translocation of GLUT4 glucose transporters in skeletal muscle as a cause of human insulin resistance. J Clin Invest 101: 2377-2386

83. Vogt B, Muhlbacher C, Carrascosa J et al. (1992) Subcellular distribution of GLUT 4 in the skeletal muscle of lean Type II (non-insulin-dependent) diabetic patients in the basal state. Diabetologia 35: 456-463

84. Folli F, Saad MJA, Backer JM, Kahn CR (1993) Regulation of phosphatidylinositol 3-kinase activity in liver and muscle of animal models of insulin-resistant and insulindeficient diabetes mellitus. J Clin Invest 92: 1787-1794

85. Saad MJA, Folli F, Kahn JA, Kahn CR (1993) Modulation of insulin receptor, insulin receptor substrate-1, and phosphatidylinositol 3-kinase in liver and muscle of dexamethasone-treated rats. J Clin Invest 92: 2065-2072 
86. Saad MJA, Araki E, Miralpeix M, Rothenberg PL, White MF, Kahn CR (1992) Regulation of insulin receptor substrate-1 in liver and muscle of animal models of insulin resistance. J Clin Invest 90: 1839-1849

87. Maegawa H, Shigeta Y, Egawa K, Kobayashi M (1991) Impaired autophosphorylation of insulin receptors from abdominal skeletal muscles in nonobese subjects with NIDDM. Diabetes 40: 815-819

88. Klein HH, Vestergaard H, Kotzke G, Pedersen O (1995) Elevation of serum insulin concentration during euglycemic hyperinsulinemic clamp studies leads to similar activation of insulin receptor kinase in skeletal muscle of subjects with and without NIDDM. Diabetes 44: 1310-1317

89. Zierath JR, Krook A, Wallberg-Henriksson H (1998) Insulin action in insulin resistant skeletal muscle from NIDDM subjects. Mol Cell Biochem 182: 153-160

90. Arner P, Pollare T, Lithell H, Livingston JN (1987) Defective insulin receptor tyrosine kinase in human skeletal muscle in obesity and Type II (non-insulin-dependent) diabetes mellitus. Diabetologia 30: 437-440

91. Kim YB, Nikoulina SE, Ciaraldi TP, Henry RR, Kahn BB (1999) Normal insulin-dependent activation of Akt/protein kinase $\mathrm{B}$, with diminished activation of phosphoinositide 3-kinase, in muscle in type 2 diabetes. J Clin Invest 104: 733-741

92. Zierath JR, He L, Guma A, Wahlström E, Klip A, Wallberg-Henriksson H (1996) Insulin action on glucose transport and plasma membrane GLUT4 content in skeletal muscle from patients with NIDDM. Diabetologia 39: 1180-1189

93. Franke TF, Yang SI, Chan TO et al. (1995) The protein kinase encoded by the Akt proto-oncogene is a target of the PDGF-activated phosphatidylinositol 3-kinase. Cell 81: 727-736

94. Alessi DR, James SR, Downes CP et al. (1997) Characterization of a 3-phosphoinositide-dependent protein kinase which phosphorylates and activates protein kinase $\mathrm{B} \alpha$. Curr Biol 7: 261-269

95. Shepherd PR, Nave BT, Rincon J et al. (1997) Involvement of phosphoinositide 3-kinase in insulin stimulation of MAP-kinase and phosphorylation of protein kinase-B in human skeletal muscle: implications for glucose metabolism. Diabetologia 40: 1172-1177

96. Ruderman NB, Saha AK, Vavvas D, Witters LA (1999) Malonyl-CoA, fuel sensing, and insulin resistance. Am J Physiol 276: E1-E18

97. Schmitz-Peiffer C, Browne CL, Oakes ND et al. (1997) Alterations in the expression and cellular localization of protein kinase $\mathrm{C}$ isozymes epsilon and theta are associated with insulin resistance in skeletal muscle of the highfat-fed rat. Diabetes 46: 169-178

98. Avignon A, Yamada K, Zhou X et al. (1996) Chronic activation of protein kinase $\mathrm{C}$ in soleus muscles and other tissues of insulin-resistant type II diabetic Goto-Kakizaki (GK), obese/aged, and obese/Zucker rats. A mechanism for inhibiting glycogen synthase. Diabetes 45: 1396-1404

99. Kawano Y, Rincon J, Soler A et al. (1999) Hyperglycemia-induced changes in glucose transport and protein kinase $\mathrm{C} \beta 2$ in rat skeletal muscle. Diabetologia 42 : 1071-1079

100. Pillay TS, Xiao S, Olefsky JM (1996) Glucose-induced phosphorylation on the insulin receptor. J Clin Invest 97: 613-620

101. Griffin ME, Marcucci MJ, Cline GW et al. (1999) Free fatty acid-induced insulin resistance is associated with activation of protein kinase $\mathrm{C}$ theta and alterations in the insulin signaling cascade. Diabetes 48: 1270-1274
102. Nagy K, Levy J, Grunberger G (1991) Impaired translocation of protein kinase $\mathrm{C}$ activity in human non-insulin-dependent diabetes mellitus. Metabolism 40: 807-813

103. Considine RV, Nyce MR, Allen LE et al. (1995) Protein kinase $\mathrm{C}$ is increased in the liver of humans and rats with non-insulin-dependent diabetes mellitus: an alteration not due to hyperglycemia. J Clin Invest 95: 2938-2944

104. Dohm G, Elton C, Friedman J et al. (1991) Decreased expression of glucose transporters in muscle from insulin-resistant patients. Am J Physiol 260: E459-E463

105. Handberg A, Vaag A, Damsbo P, Beck-Nielsen H, Vinten J (1990) Expression of insulin-regulatable glucose transporters in skeletal muscle from Type II (non-insulin-dependent) diabetic patients. Diabetologia 33: 625-627

106. Pedersen O, Bak JF, Andersen PH et al. (1990) Evidence against altered expression of GLUT1 or GLUT4 in skeletal muscle of patients with obesity or NIDDM. Diabetes 39: $865-870$

107. Jullien D, Tanti J-F, Heydrick S et al. (1993) Differential effects of okadaic acid on insulin-stimulated glucose and amino acid uptake and phosphatidylinositol 3-kinase activity. J Biol Chem 268: 15246-15251

108. Kahn BB, Schulman GI, DeFronzo RA, Cushman SW, Rossetti L (1991) Normalization of blood glucose in diabetic rats with phlorizin treatment reverses insulin-resistant glucose transport in adipose cells without restoring glucose transporter gene expression. J Clin Invest 87 : 561-570

109. Rossetti L, Smith D, Schulman GI, Papachristou D, De Fronzo RA (1987) Correction of hyperglycemia with phlorizin normalizes tissue sensitivity to insulin in diabetic rats. J Clin Invest 79: 1510-1515

110. Rossetti L, Hawkins M, Chen W, Gindi J, Barzilai N (1997) In vivo glucosamine infusion induces insulin resistance in normoglycemic but not hyperglycemic conscious rats. J Clin Invest 96: 132-140

111. Henry RR, Wallace P, Olefsky JM (1986) Effects of weight loss on mechanisms of hyperglycemia in obese non-insulin-dependent diabetes mellitus. Diabetes 35: 990-998

112. Friedman JE, Dohm GL, Leggett-Frazier N et al. (1992) Restoration of insulin responsiveness in skeletal muscle of morbidly obese patients after weight loss. J Clin Invest 89: 701-705

113. Kolterman OG, Gray RS, Shapiro G, Scarlett JA, Griffin J, Olefsky JM (1984) The acute and chronic effects of sulfonylurea therapy in type II diabetic subjects. Diabetes 33: $346-354$

114. Greenfield H, Doberne L, Rosenthal M, Schulz B, Widstrom A, Reaven GM (1982) Effect of sulfonylurea treatment on in vivo insulin secretion and action in patients with non-insulin-dependent diabetes mellitus. Diabetes 31: 307-312

115. Ginsberg H, Rayfield EJ (1981) Effect of insulin therapy on insulin resistance in type II diabetic subjects. Evidence for heterogeneity. Diabetes 30: 739-745

116. Garvey WT, Olefsky JM, Griffin J, Hamman RF, Kolterman OG (1985) The effect of insulin treatment on insulin secretion and insulin action in type II diabetes mellitus. Diabetes 34: 222-234

117. Yki-Järvinen H, Helve E, Koivisto V (1987) Hyperglycemia decreases glucose uptake in type I diabetes. Diabetes 36: 892-896

118. Friedman JE, Ishizuka T, Shao J, Huston L, Highman T, Catalano P (1999) Impaired glucose transport and insulin receptor tyrosine phosphorylation in skeletal muscle from obese women with gestational diabetes. Diabetes 48: 1807-1814 
119. Goto Y, Suzuki K-I, Sasaki M, Ono T, Abe S (1988) GK rat as a model of non-obese non-insulin-dependent diabetes: selective breeding over 35 generations. In: Shafrir E, Renold A (eds) Frontiers in Diabetes Research. Lessions from Animal Diabetes. John Libbey, London, pp 301-303

120. Kurowski TG, Lin Y, Luo Z et al. (1999) Hyperglycemia inhibits insulin activation of Akt/protein kinase B, but not phosphatidylinositol 3-kinase in rat skeletal muscle. Diabetes 48: 658-663

121. Wallberg-Henriksson H (1987) Glucose transport in skeletal muscle. Influence of contractile activity, insulin, catecholamines, and diabetes mellitus. Acta Physiol Scand 131: $1-80$

122. Richter EA, Garetto LP, Goodman MN, Ruderman NB (1982) Muscle glucose metabolism following exercise in the rat. J Clin Invest 69: 785-793

123. Richter EA, Garetto LP, Goodman MN, Ruderman NB (1984) Enhanced muscle glucose metabolism after exercise: modulation by local factors. Am J Physiol 246: E476-E482

124. Lund S, Flyvbjerg A, Holman GD, Larsen FS, Pedersen O, Schmitz O (1994) Comparative effects of IGF-1 and insulin on the glucose-transporter system in rat muscle. Am J Physiol 267: E461-E466

125. Cartee GD, Douen AG, Ramlal T, Klip A, Holloszy JO (1991) Stimulation of glucose transport in skeletal muscle by hypoxia. J Appl Physiol 70: 1593-1600

126. Zierath JR, Tsao T-S, Stenbit AE, Ryder JW, Galuska D, Charron MJ (1998) Restoration of hypoxia-stimulated glucose uptake in GLUT4-deficient muscles by musclespecific GLUT4 transgenic complementation. J Biol Chem 273: 20910-20915

127. Vavvas D, Apazidis A, Saha AK et al. (1997) Contraction-induced changes in acetyl-CoA carboxylase and 5'AMP-activated kinase in skeletal muscle. J Biol Chem 272: 13255-13261

128. Hayashi T, Hirshman MF, Kuth EJ, Winder WW, Goodyear LJ (1998) Evidence for 5'-AMP-activated protein kinase mediation of the effect of muscle contraction on glucose transport. Diabetes 47: 1369-1373

129. Youn JH, Gulve EA, Holloszy JO (1991) Calcium stimulates glucose transport in skeletal muscle by a pathway independent of contraction. Am J Physiol 260:C555-C561

130. Youn JH, Gulve EA, Henriksen EJ, Holloszy JO (1994) Interactions between effects of $\mathrm{W}-7$, insulin, and hypoxia on glucose transport in skeletal muscle. Am J Physiol 267: R888-R894

131. Douen AG, Ramlal T, Rastogi SA et al. (1990) Exercise induces recruitment of the "insulin responsive" glucose transporter. Evidence for distinct intracellular insulinand exercise-recruitable transporter pools in skeletal muscle. J Biol Chem 265: 13427-13430

132. Wallberg-Henriksson H, Holloszy JO (1984) Contractile activity increases glucose uptake by muscle in severely diabetic rats. J Appl Physiol 57: 1045-1049

133. Wallberg-Henriksson H, Constable SH, Young DA, Holloszy JO (1988) Glucose transport into rat skeletal muscle: interaction between exercise and insulin. J Appl Physiol 65: 909-913

134. Wahren J, Hagenfeldt L, Felig P (1975) Splanchnic and leg exchange of glucose, amino acids, and free fatty acids during exercise in diabetes mellitus. $\mathrm{J}$ Clin Invest 55: 1303-1314

135. Hübingen A, Franzen A, Gries FA (1987) Hormonal and metabolic response to physical exercise in hyperinsulinaemic and nonhyperinsulinaemic type 2 diabetics. Diabetes Res Clin Pract 4: 57-61
136. Schneider SH, Vitug A, Ruderman NB (1986) Atherosclerosis and physical activity. Diabetes Metab Rev 1: 514-553

137. Larsen JJ, Dela F, Kjaer M, Galbo H (1997) The effect of moderate exercise on postprandial glucose homeostasis in NIDDM patients. Diabetologia 40: 447-453

138. Minuk HL, Vranic M, Marliss EB, Hanna AK, Albisser AM, Zinman B (1981) Glucoregulatory and metabolic response to exercise in obese noninsulin-dependent diabetes. Am J Physiol 240: E458-E464

139. Burstein R, Epsteinm Y, Shapiro Y, Charuzi I, Karnieli E (1990) Effect of an acute bout of exercise on glucose disposal in human obesity. J Appl Physiol 69: 299-304

140. Kennedy JW, Hirshman MF, Gervino EV et al. (1999) Acute exercise induces GLUT4 translocation in skeletal muscle of normal human subjects and subjects with type 2 diabetes. Diabetes 48: 1192-1197

141. Rodgers MA, Yamamoto C, King DS, Hagberg JM, Ehsani AA, Holloszy JO (1988) Improvement in glucose tolerance after 1 wk of exercise in patients with mild NIDDM. Diabetes Care 11: 613-618

142. Hughes VA, Fiatarone MA, Fielding RA et al. (1993) Exercise increases muscle GLUT4-levels and insulin action in subjects with impaired glucose tolerance. Am J Physiol 264: E855-E862

143. Rodnick KJ, Henriksen EJ, James DE, Holloszy JO (1992) Exercise training, glucose transporters, and glucose transport in rat skeletal muscles. Am J Physiol 262: C9-C14

144. Ploug T, Stallknecht BM, Pedersen O et al. (1900) Effect of endurance training on glucose transport capacity and glucose transporter expression in rat skeletal muscle. Am J Physiol 259: E778-E786

145. Houmard JA, Egan PC, Neufer PD et al. (1991) Elevated skeletal muscle glucose transporter levels in exercisetrained middle-aged men. Am J Physiol 261: E437-E443

146. Houmard JA, Shinebarger MH, Dolan PL et al. (1993) Exercise training increases GLUT-4 protein concentration in previously sedentary middle-aged men. Am J Physiol 264: E896-E901

147. Andersen PH, Lund S, Schmitz O, Junker S, Kahn BB, Pedersen O (1993) Increased insulin-stimulated glucose uptake in athletes: the importance of GLUT4 mRNA, GLUT4 protein and fibre type composition of skeletal muscle. Acta Physiol Scand 149: 393-404

148. Dela F, Handberg A, Mikines KJ, Vinten J, Galbo H (1993) GLUT4 and insulin receptor binding and kinase activity in trained human muscle. J Physiol 469: 615-624

149. Hjeltnes N, Galuska D, Björnholm M et al. (1998) Exercise-induced overexpression of key regulatory proteins involved in glucose uptake and metabolism in tetraplegic persons: molecular mechanism for improved glucose homeostasis. FASEB J 12: 1701-1712

150. Vestergaard H, Bjøjbæk C, Hansen T, Larsen FS, Granner DK, Pedersen P (1995) Impaired activity and gene expression of hexokinase II in muscle from non-insulindependent diabetes mellitus patients. J Clin Invest 96: 2639-2645

151. Mandarino LJ, Printz RL, Cusi KA et al. (1995) Regulation of hexokinase II and glycogen synthase mRNA, protein, and activity in human muscle. Am J Physiol 269: E701-E708

152. Bak JF, Pedersen O (1990) Exercise-activation of glycogen synthase in human skeletal muscle. Am J Physiol 258: E957-E963

153. Vestergaard H, Bjorbaek C, Andersen PH, Bak JF, Pedersen O (1991) Impaired expression of glycogen synthase 
mRNA in skeletal muscle of NIDDM patients. Diabetes 40: $1740-1745$

154. Vestergaard H, Lund S, Larsen FS, Bjerrum OJ, Pedersen O (1993) Glycogen synthase and phosphofructokinase protein and mRNA levels in skeletal muscle from insulin-resistant patients with non-insulin-dependent diabetes mellitus. J Clin Invest 91: 2342-2350

155. Goodyear LJ, Chang P-Y, Sherwood DJ, Durfesne SD, Moller DE (1996) Effects of exercise and insulin on mitogen-activated protein kinase signaling pathways in rat skeletal muscle. Am J Physiol 271: E403-E408

156. Aronson D, Violan MA, Dufresne SD, Zangen D, Fielding RA, Goodyear LJ (1997) Exercise stimulates the mitogenic-activated protein kinase pathway in human skeletal muscle. J Clin Invest 99: 1251-1257

157. Aronson D, Dufresne SD, Goodyear LJ (1997) Contractile activity stimulates the c-Jun NH2-terminal kinase pathway in rat skeletal muscle. J Biol Chem 272: 25636-25640

158. Widegren U, Jiang XJ, Krook A et al. (1998) Divergent effects of exercise on metabolic and mitogenic signaling pathways in human skeletal muscle. FASEB J 12: 1379-1389

159. Ryder JW, Fahlman R, Wallberg-Henriksson H, Alessi DR, Krook A, Zierath JR (2000) Effect of contraction on mitogen-activated protein kinase signal transduction in skeletal muscle: involvement of the mitogen- and stress-activated protein kinase 1. J Biol Chem 275: 1457-1462

160. Cohen P (1997) The search for physiological substrates of MAP and SAP kinases in mammalian cells. Trends Cell Biol 7: 353-361

161. Hansen PA, Gulve EA, Marshall BA et al. (1995) Skeletal muscle glucose transport and metabolism are enhanced in transgenic mice overexpressing the GLUT4 glucose transporter. J Biol Chem 270: 1679-1684

162. Ren J-M, Marshall BA, Mueckler MM, McCaleb M, Amatruda JM, Schulman GI (1995) Overexpression of GLUT4 protein in muscle increases basal and insulinstimulated whole body glucose disposal in conscious mice. J Clin Invest 95: 429-432
163. Tsao T-S, Stenbit A, Li J et al. (1997) Muscle-specific transgenic complementation of GLUT4-deficient mice: preferential effects of glucose but not lipid metabolism. J Clin Invest 100: 671-677

164. Tsao TS, Burcelin R, Katz EB, Huang L, Charron MJ (1996) Enhanced insulin action due to targeted GLUT4 overexpression exclusively in muscle. Diabetes 45: 28-36

165. Ikemoto S, Thompson KS, Takahashi M, Itakura H, Lane MD, Ezaki O (1995) High fat diet-induced hyperglycemia: prevention by low level expression of a glucose transporter (GLUT4) minigene in transgenic mice. Proc Natl Acad Sci USA 92: 3096-3099

166. Leturque A, Loizeau M, Vaulont S, Salminen M, Girard J (1996) Improvement of insulin action in diabetic transgenic mice selectively overexpressing GLUT4 in skeletal muscle. Diabetes 45: 23-27

167. Gibbs EM, Stock JL, McCoid SC et al. (1995) Glycemic improvement in diabetic $\mathrm{db} / \mathrm{db}$ mice by overexpression of the human insulin-regulatable glucose transporter (GLUT4). J Clin Invest 95: 1512-1518

168. Fink RI, Wallace P, Brechtel G, Olefsky JM (1992) Evidence that glucose transport is rate-limiting for in vivo glucose uptake. Metabolism 41: 867-902

169. Yki-Jarvinen H, Young AA, Lamkin C, Foley JE (1987) Kinetics of glucose disposal in whole body and across the forearm in man. J Clin Invest 79: 1713-1719

170. Chang P-Y, Jensen J, Printz RL, Granner DK, Ivy JI, Moller DE (1996) Overexpression of hexokinase II in transgenic mice. J Biol Chem 271: 14834-14839

171. Dela F, Mikines KJ, von Linstow M, Secher NH, Galbo H (1992) Effect of training on insulin-mediated glucose uptake in human muscle. Am J Physiol 263: E1134-E1143

172. Kim Y, Inoue T, Nakajima R et al. (1995) Effects of endurance training on gene expression of insulin signal transduction pathway. Biochem Biophys Res Commun 210: 766-773

173. Chibalin AV, Yu M, Ryder JW et al. (2000) Exercise-induced changes in expression and activity of proteins involved in insulin signal transduction in skeletal muscle: differential effects on insulin receptor substrates 1 and 2. Proc Natl Acad Sci USA 97: 38-43 